\title{
Water-spray washing technique as a purification process in the production of biodiesel
}

\author{
Warunee Limmun ${ }^{1}$, and Sansanee Sansiribhan ${ }^{2 *}$ \\ ${ }^{1}$ King Mongkut's Institute of Technology Ladkrabang, Prince of Chumphon Campus, Department of \\ Engineering, Chumphon, Thailand \\ ${ }^{2}$ Suan Sunandha Rajabhat University, Faculty of Science and Technology, Applied Physics Program, \\ Bangkok, Thailand
}

\begin{abstract}
In order to meet the standards set for biodiesel after biodiesel production via transesterification, a purification process is necessary. For the purification process, the wet washing method is mostly recommended because it is well-known for its easy application and high efficiency. However, this method requires a large volume of water and takes a long time. Consequently, this study focuses on designing a washing machine that reduces the amount of water used and shortens the application time for the washing method. The spray washing technique, a type of the wet washing method, was used for this study with a focus on the following parameters: the volume of water to crude biodiesel, flow rate, and time. All conditions investigated in the basic standards of biodiesel. The $\mathrm{pH}$ value, density, and velocity were considered as the criteria to select the optimum conditions for the washing machine. The results indicated that a volume ratio of $0.8: 1$ (water:crude biodiesel) and a flow rate of $4 \mathrm{~L} / \mathrm{min}$ for $0.5 \mathrm{~min}$ was the optimum condition of the water washing machine for biodiesel purification that meets the international biodiesel specifications.
\end{abstract}

\section{Introduction}

The rising energy demand and increasing cost of energy have resulted in growing research in alternative and renewable fuels that are less damaging to the environment [1]. Biodiesel that is produced from edible and non-edible oils via transesterification is a promising alternative to diesel fuel. It is sustainable and environment-friendly by lowering gas emissions [2]. Biodiesel production involves the following steps: transesterification, separation, and purification processes that are responsible for biodiesel production cost. Suthar et al. [3] reported that $60 \%$ to $80 \%$ of the total procedure costs of biodiesel production was associated with separation and purification processes. Transesterification is the conversion of triglycerides in oils into alkyl ester (crude biodiesel) in the presence of alcohol and a catalyst, with glycerol as a by-product [4]. The main catalysts used are bases, acids, and enzymes. The base catalysts such as potassium hydroxide $(\mathrm{KOH})$ or sodium hydroxide $(\mathrm{NaOH})$ are mostly used because they are relatively low cost and increase the rate of transesterification. After transesterification, glycerol is separated from crude biodiesel by gravity separation or

* Corresponding author: mailto:sansanee.sa@ssru.ac.th 
centrifugation. The crude biodiesel has to be purified to remove various impurities, such as unconverted triacylglycerols, glycerol, residual catalyst, soaps, and others, to prevent damage to diesel engines. Moreover, the formation of soap decreases the purity and yield of biodiesel, making it difficult to separate and purify the product [5]. Accordingly, the washing process is the most important for biodiesel production and is required to improve its biodiesel properties. After the purification process, biodiesel is heated to evaporate the residual water in the product. The purification of biodiesel should be in compliance with the biodiesel specifications such as ASTM D6751 or EN 14214.

The two recognized methods of purification are wet and dry washing. The dry washing involves the use of adsorbent compounds and cation-exchange to remove impurities. Membrane extraction can also be applied for purification biodiesel. However, this is an expensive process, and having a short operation time further increases the cost of biodiesel production. Moreover, biodiesel produced by dry washing purification does not meet the standard specifications [3]. Conversely, the wet washing with water, such as a stirring method and bubble method, is commonly performed for biodiesel purification because it is simple, economical, and could remove soaps formation due to their water solubility $[6,7]$. The removal process of impurities is complete when the washing water is clear. Rahayu and Mindaryani [8] studied the optimization of biodiesel washing by stirring. The results showed that the slowly stirring restricted the formation of an emulsion. The volume ratio of biodiesel to water and temperature increased with decreasing of glycerol from biodiesel. The optimum volume ratio was 300 to 1 (water:biodiesel) for biodiesel water washing, and the final $\mathrm{pH}$ value of biodiesel was reduced to a neutral $\mathrm{pH}$ with the multistage washing process. Srivastava and Verma [9] reported that washing biodiesel with a bubble wash method required more than 24 hours, and this process needed to be repeated three times. Therefore, the bubble wash method is inefficient for large biodiesel production. Berrios and Skelton [6] compared wet and dry biodiesel washing methods, indicating that purified biodiesel by wet washing method satisfies the EN14214 standards.

Hot water washing, another wet washing method, has been shown to increase the yield and purity of biodiesel and meets the biodiesel standards [10]. Atadashi et al. [11] reported that the unreacted catalysts and glycerol could be removed using hot water washing at $60^{\circ} \mathrm{C}$ and volume ratios from 1:1 to 3:1 (water:biodiesel) after $20 \mathrm{~min}$. Moreover, washing with hot water can enhance purity and yield, while satisfied the biodiesel specifications.

Another commonly used wet washing method is the spray washing technique, where water is spread over the surface of the biodiesel and then allowed to separate the layers. The weaknesses of this technique are a large washing tank is needed and has very long wash times. Additionally, the large droplets of water can increase agitation leading to the formation of undesirable biodiesel emulsion. The water washing method requires a high amount of water (stirring method), time (bubble method), and energy to purify biodiesel [12].

To overcome these disadvantages, a novel design for the water washing machine, using the spray washing technique, is proposed in this study. In addition, the appropriate conditions: the volume of water to biodiesel, flow rate, and reaction time for the water washing machine were investigated.

\section{Materials and methods}

\subsection{Materials}

Palm oil was purchased from Natural Palm Oil Co. Ltd, Thailand. Methanol (MeOH, purity: 99.85\%) was supplied by Lab Scan Asia Ltd., Thailand, and potassium hydroxide ( $\mathrm{KOH}$, reagent grade) was purchased from Merck, Thailand. 


\subsection{Biodiesel Preparation}

Biodiesel was produced using the method reported by Atadashi et al. [13], with some modifications. Briefly, the concentration of potassium hydroxide of $1 \% \mathrm{wt}$ was used as a catalyst for the transesterification reaction. $\mathrm{KOH}$ and methanol were pre-mixed to prepare potassium methoxide. The molar ratio of methanol to palm oil was $6: 1$. Afterward, palm oil and potassium methoxide were added to the reactor. The transesterification reaction was carried out in a batch reactor and stirred at $750 \mathrm{rpm}$ for $45 \mathrm{~min}$. The reaction temperature was set at $60^{\circ} \mathrm{C}$. After the reaction was completed, the mixture of biodiesel and glycerin was allowed to separate by gravity separation for $24 \mathrm{~h}$. The bottom glycerol layer was removed, then the upper layer of crude biodiesel was then transferred to the feed tank for the purification process. The $\mathrm{pH}$ value of crude biodiesel before washing was $8.9 \pm 0.2$.

\subsection{Experimental apparatus}

The spray washing technique at a low flow rate was designed to restrict the emulsion of biodiesel, improve water-saving, and enhance effective washing. The structure and schematic diagram of the water washing machine using the spray washing technique is shown in Figures. 1 and 2. The water washing machine is mainly composed of a washing reactor, and a storage tank for crude biodiesel and tap water separately. Stainless steel reactor and storage tanks were used. The crude biodiesel $(1 \mathrm{~L})$ was discharged into a 5-L storage tank after the removal of glycerol. The tap water at $60^{\circ} \mathrm{C}$ and crude biodiesel were injected into the reactor using the flat fan nozzle. The crude biodiesel pump and nozzle feed into the middle of the washing reactor. The tap water spray nozzle is placed on both sides of the reactor. In this study, experimental tests were performed to examine the flow rate, a volume ratio of water to biodiesel, and the time required to achieve a low amount of water for washing and to purify crude biodiesel.
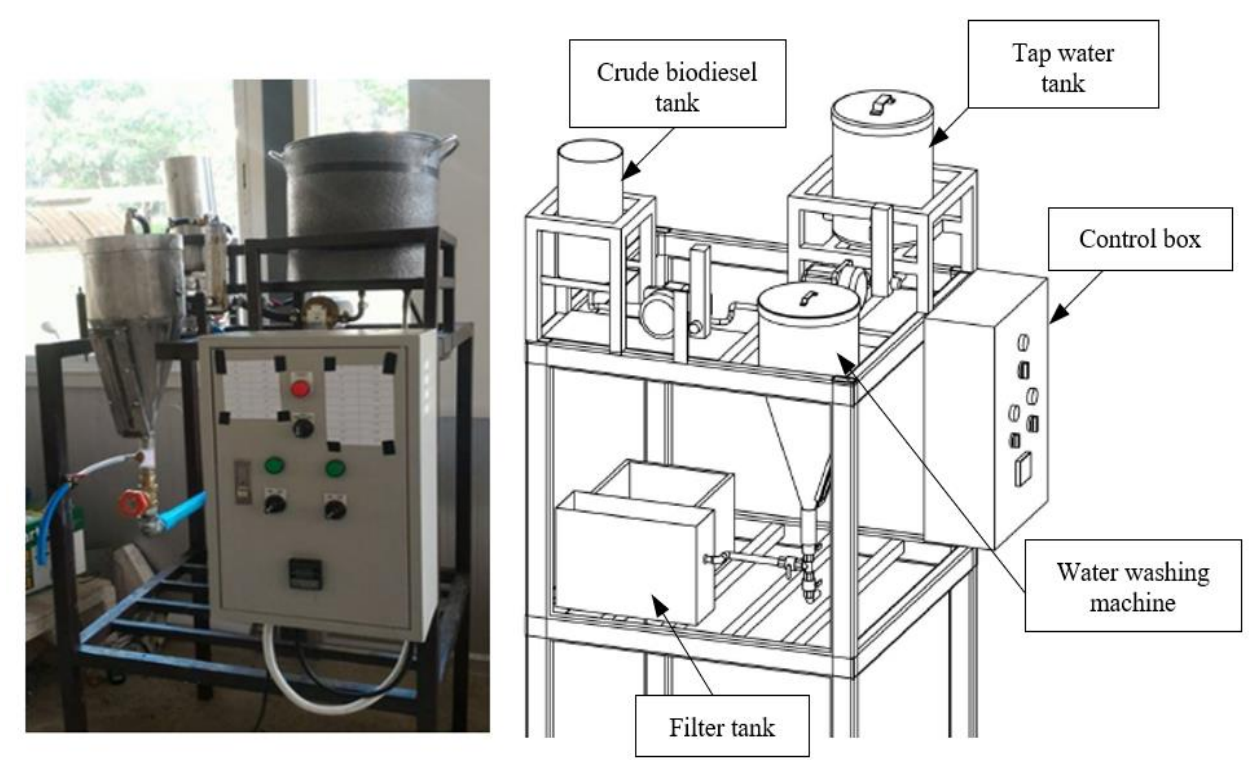

Fig. 1. Water washing machine for purification of biodiesel. 


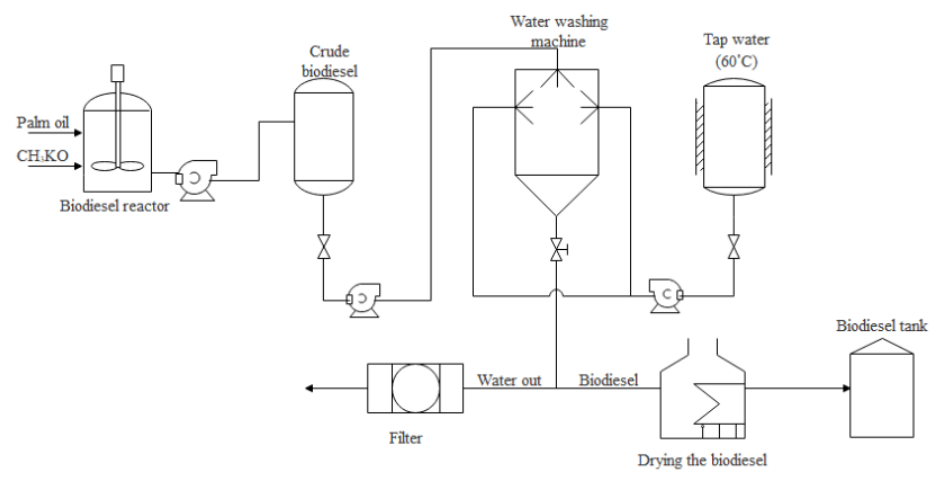

Fig. 2. Schematic representation of the experimental setup.

\subsection{Experimental procedure}

The crude biodiesel was collected for further purification using a water washing machine. The crude biodiesel and tap water at $60^{\circ} \mathrm{C}$ were added to the reactor by spraying to increase contact between two liquids. The effects of water volume, flow rate, and time on the washing process were investigated to determine the appropriate parameters for biodiesel purification. The total flow rate was set at $2-4 \mathrm{~L} / \mathrm{min}$. The volume ratio of tap water to crude biodiesel was set at $0.8: 1-2.5: 1$. The washing process was repeated three times. After the washing process, the water in the sample was separated by gravity for 1 hour in the reactor. Then, the water layer was drained, while the biodiesel layer was dried to remove any residual water before analyzing biodiesel properties. All experiments were carried out in triplicate. The differences in mean values were evaluated by one-way analysis of variance (ANOVA) using SPSS. The result of ANOVA does not provide detailed information regarding the differences among various combinations of groups. The analysis of the differences between particular pairs of experimental groups was performed by using the LSD method as the multiple comparison test.

\subsection{Analytical Methods}

The characteristics of biodiesel were evaluated according to the biodiesel standards EN 14214 (2012) or ASTM D6751 (12). The density limits in biodiesel ranged from 860 to 900 $\mathrm{kg} / \mathrm{m}^{3}$ at $15^{\circ} \mathrm{C}$, according to the EN 12185 standard. The kinematic viscosity at $40^{\circ} \mathrm{C}$, using glass capillary viscometers, ranged from 1.9 to $6 \mathrm{~mm}^{2} / \mathrm{s}$, according to the ASTM D445 standard.

\section{Results and discussion}

\subsection{Investigation of water washing machine parameters on the $\mathrm{pH}$ values of biodiesel}

The volume ratios of tap water to crude biodiesel were $0.8: 1,1.25: 1$, and $2.5: 1$. The total flow rate was set at 2,3, and $4 \mathrm{~L} / \mathrm{min}$. The washing time was $0.5,1$, and $2 \mathrm{~min}$. All conditions of the washing process using the water washing machine were repeated three times. The effect of these three conditions on the purification process was shown in Table 1. The temperature and initial $\mathrm{pH}$ value of tap water were $60 \pm 1{ }^{\circ} \mathrm{C}$ and $7.42 \pm 0.01$, respectively. This result 
showed that the $\mathrm{pH}$ value of the first washing was higher than that of the second and third washing, indicating that increasing the number of washing processes reduced the $\mathrm{pH}$ value of biodiesel, close to that of tap water. Furthermore, the $\mathrm{pH}$ value of biodiesel decreased with an increasing volume ratio of tap water to crude biodiesel from $0.8: 1$ to $2.5: 1$ under the same flow rate and time. In biodiesel purification, the lowest $\mathrm{pH}$ value using a water washing machine occurred at the highest volume ratio of $2.5: 1$, which, consistent with other studies [14], recommended the volume ratio of 2.5:1 (water:crude biodiesel) for washing biodiesel in a microtube reactor. Our result demonstrated that a higher amount of water removed impurities in biodiesel in the washing process.

Table 1. The comparison of biodiesel $\mathrm{pH}$ values with a number of washing steps in different parameters.

\begin{tabular}{|c|c|c|c|c|c|c|}
\hline \multirow{2}{*}{$\begin{array}{c}\text { Water:Crude } \\
\text { biodiesel }\end{array}$} & \multirow{2}{*}{$\begin{array}{c}\text { Flow rate } \\
\text { (L/min) }\end{array}$} & \multirow{2}{*}{$\begin{array}{l}\text { Time } \\
(\min )\end{array}$} & \multicolumn{4}{|c|}{ pH } \\
\hline & & & Avg. 1 st & Avg. 2 nd & Avg. 3 rd & $\begin{array}{c}\text { Overall } \\
\text { Avg. }\end{array}$ \\
\hline \multirow{9}{*}{$0.8: 1$} & \multirow{3}{*}{2} & 0.5 & $8.83 \pm 0.01^{\mathrm{c}}$ & $7.64 \pm 0.01^{\mathrm{fg}}$ & $7.51 \pm 0.00^{\mathrm{d}}$ & $7.99 \pm 0.63$ \\
\hline & & 1 & $8.84 \pm 0.00^{\mathrm{b}}$ & $7.66 \pm 0.00^{\mathrm{cd}}$ & $7.55 \pm 0.00^{b}$ & $8.02 \pm 0.62$ \\
\hline & & 2 & $8.86 \pm 0.00^{\mathrm{a}}$ & $7.69 \pm 0.00^{\mathrm{a}}$ & $7.58 \pm 0.00^{\mathrm{a}}$ & $8.04 \pm 0.61$ \\
\hline & \multirow{3}{*}{3} & 0.5 & $8.70 \pm 0.00^{\mathrm{h}}$ & $7.64 \pm 0.00^{\mathrm{g}}$ & $7.49 \pm 0.00^{\mathrm{e}}$ & $7.94 \pm 0.57$ \\
\hline & & 1 & $8.72 \pm 0.00^{\mathrm{g}}$ & $7.65 \pm 0.00^{\mathrm{de}}$ & $7.52 \pm 0.00^{\mathrm{c}}$ & $7.97 \pm 0.57$ \\
\hline & & 2 & $8.83 \pm 0.01^{\mathrm{c}}$ & $7.68 \pm 0.00^{b}$ & $7.55 \pm 0.00^{b}$ & $8.02 \pm 0.61$ \\
\hline & \multirow{3}{*}{4} & 0.5 & $8.64 \pm 0.01^{1}$ & $7.57 \pm 0.00^{\mathrm{k}}$ & $7.47 \pm 0.00^{\mathrm{g}}$ & $7.89 \pm 0.57$ \\
\hline & & 1 & $8.67 \pm 0.01^{j}$ & $7.60 \pm 0.00^{\mathrm{i}}$ & $7.49 \pm 0.00^{\mathrm{e}}$ & $7.92 \pm 0.56$ \\
\hline & & 2 & $8.75 \pm 0.01^{\mathrm{e}}$ & $7.65 \pm 0.00^{\text {ef }}$ & $7.51 \pm 0.00^{\mathrm{d}}$ & $7.97 \pm 0.59$ \\
\hline \multirow{9}{*}{$1.25: 1$} & \multirow{3}{*}{2} & 0.5 & $8.72 \pm 0.00^{\mathrm{g}}$ & $7.62 \pm 0.01^{\mathrm{h}}$ & $7.46 \pm 0.00^{\mathrm{gh}}$ & $7.93 \pm 0.59$ \\
\hline & & 1 & $8.78 \pm 0.00^{\mathrm{d}}$ & $7.64 \pm 0.00^{\mathrm{fg}}$ & $7.53 \pm 0.00^{\mathrm{c}}$ & $7.98 \pm 0.60$ \\
\hline & & 2 & $8.83 \pm 0.00^{c}$ & $7.67 \pm 0.00^{c}$ & $7.54 \pm 0.00^{b}$ & $8.01 \pm 0.61$ \\
\hline & \multirow{3}{*}{3} & 0.5 & $8.66 \pm 0.00^{\mathrm{k}}$ & $7.61 \pm 0.01^{\mathrm{i}}$ & $7.45 \pm 0.01^{\mathrm{i}}$ & $7.91 \pm 0.57$ \\
\hline & & 1 & $8.68 \pm 0.00^{\mathrm{i}}$ & $7.64 \pm 0.00^{\mathrm{fg}}$ & $7.49 \pm 0.00^{\mathrm{e}}$ & $7.94 \pm 0.56$ \\
\hline & & 2 & $8.76 \pm 0.00^{\mathrm{e}}$ & $7.65 \pm 0.00^{\mathrm{de}}$ & $7.52 \pm 0.01^{\mathrm{c}}$ & $7.98 \pm 0.59$ \\
\hline & \multirow{3}{*}{4} & 0.5 & $8.63 \pm 0.01^{\mathrm{m}}$ & $7.54 \pm 0.01^{\mathrm{m}}$ & $7.43 \pm 0.00^{j}$ & $7.87 \pm 0.57$ \\
\hline & & 1 & $8.67 \pm 0.00^{j}$ & $7.57 \pm 0.00^{\mathrm{k}}$ & $7.45 \pm 0.00^{\mathrm{hi}}$ & $7.90 \pm 0.58$ \\
\hline & & 2 & $8.74 \pm 0.00^{\mathrm{f}}$ & $7.61 \pm 0.01^{\mathrm{i}}$ & $7.49 \pm 0.01^{\mathrm{e}}$ & $7.95 \pm 0.60$ \\
\hline \multirow{9}{*}{$2.5: 1$} & \multirow{3}{*}{2} & 0.5 & $8.63 \pm 0.00^{\mathrm{m}}$ & $7.52 \pm 0.01^{\mathrm{n}}$ & $7.45 \pm 0.01^{\mathrm{i}}$ & $7.87 \pm 0.57$ \\
\hline & & 1 & $8.66 \pm 0.01^{\mathrm{jk}}$ & $7.55 \pm 0.00^{1}$ & $7.46 \pm 0.00^{\mathrm{g}}$ & $7.89 \pm 0.58$ \\
\hline & & 2 & $8.69 \pm 0.00^{\mathrm{i}}$ & $7.58 \pm 0.01^{\mathrm{j}}$ & $7.48 \pm 0.00^{\mathrm{f}}$ & $7.91 \pm 0.58$ \\
\hline & \multirow{3}{*}{3} & 0.5 & $8.62 \pm 0.00^{\mathrm{m}}$ & $7.50 \pm 0.00^{\circ}$ & $7.44 \pm 0.00^{\mathrm{j}}$ & $7.85 \pm 0.58$ \\
\hline & & 1 & $8.65 \pm 0.00^{1}$ & $7.54 \pm 0.01^{\mathrm{m}}$ & $7.45 \pm 0.00^{\mathrm{i}}$ & $7.88 \pm 0.58$ \\
\hline & & 2 & $8.66 \pm 0.00^{\mathrm{k}}$ & $7.55 \pm 0.00^{1}$ & $7.46 \pm 0.01^{\mathrm{gh}}$ & $7.88 \pm 0.56$ \\
\hline & \multirow{3}{*}{4} & 0.5 & $8.61 \pm 0.00^{\mathrm{n}}$ & $7.46 \pm 0.01^{\mathrm{p}}$ & $7.42 \pm 0.00^{\mathrm{k}}$ & $7.83 \pm 0.59$ \\
\hline & & 1 & $8.62 \pm 0.00^{\mathrm{m}}$ & $7.52 \pm 0.01^{\mathrm{n}}$ & $7.44 \pm 0.00^{j}$ & $7.86 \pm 0.57$ \\
\hline & & 2 & $8.64 \pm 0.00^{1}$ & $7.55 \pm 0.00^{\mathrm{Im}}$ & $7.45 \pm 0.00^{\mathrm{i}}$ & $7.88 \pm 0.57$ \\
\hline
\end{tabular}

Values with different superscripts in a column were significantly different $(\mathrm{p}<0.05)$.

The effect of the flow rate on the $\mathrm{pH}$ value of biodiesel for the washing machine was investigated. At volume ratio of $2.5: 1$, the $\mathrm{pH}$ values of biodiesel decreased from $7.45 \pm 0.01$, $7.44 \pm 0.00$ and $7.42 \pm 0.00$ for 0.5 min with a flow rate of 2,3 , and $4 \mathrm{~L} / \mathrm{min}$, respectively. The results showed that the $\mathrm{pH}$ of biodiesel reduced with the increasing flow rate.

The effect of residence time on the $\mathrm{pH}$ values of biodiesel was also observed. At volume ratio of $0.8: 1$ and flow rate of $4 \mathrm{~L} / \mathrm{min}$, the $\mathrm{pH}$ values of biodiesel increased from $8.64 \pm 0.01$ to $8.75 \pm 0.01$ in first washing step and $7.47 \pm 0.00$ to $7.51 \pm 0.00$ in third washing step when residence time was 0.5 and $2 \mathrm{~min}$, respectively. Furthermore, when the time of washing 
process increased from 0.5 to $2 \mathrm{~min}$, the $\mathrm{pH}$ values slightly rose from $8.61 \pm 0.00$ to $8.64 \pm$ 0.01 in first washing step and $7.42 \pm 0.00$ to $7.45 \pm 0.00$ in third washing step at volume ratios of 2.5:1 and flow rate of $4 \mathrm{~L} / \mathrm{min}$. The $\mathrm{pH}$ values of biodiesel slightly increased as the residence time increased from 0.5 to $2 \mathrm{~min}$, with increasing the number of washing steps. This increasing trend in $\mathrm{pH}$ with time is because some water remains in the washing machine.

\subsection{Investigations of water washing machine parameters on density and kinematic viscosity of biodiesel}

For diesel engines, the density and viscosity of biodiesel are important fuel parameters that can cause engine performance problems. In this study, after the wet washing process, the density and viscosity in each condition were measured. The effects of the volume ratio of tap water to crude biodiesel, flow rate, time on the density, and kinematic viscosity of biodiesel after purification by water washing machine are presented in Table 2 . The results indicated that the density and viscosity of biodiesel decreased markedly after repeated washing three times. The density of biodiesel was not significantly different between several parameters of biodiesel after washing by water washing machine. The density of biodiesel ranged from 871 to $875 \mathrm{~kg} / \mathrm{m}^{3}$, which met the EN 14214 (2012) standards.

Table 2. The density and kinematic viscosity of biodiesel after washing by a water washing machine in different parameters.

\begin{tabular}{|c|c|c|c|c|}
\hline Water:Crude biodiesel & $\begin{array}{c}\text { Flow rate } \\
\text { (L/min) }\end{array}$ & $\begin{array}{l}\text { Time } \\
(\min )\end{array}$ & $\begin{array}{l}\text { Density } \\
\left(\mathrm{kg} / \mathrm{m}^{3}\right)\end{array}$ & $\begin{array}{c}\text { Kinematic } \\
\text { viscosity } \\
\left(\mathrm{mm}^{2} / \mathbf{s}\right)\end{array}$ \\
\hline \multirow{9}{*}{$0.8: 1$} & \multirow{3}{*}{2} & 0.5 & $873 \pm 0.58^{\text {bcde }}$ & $4.89 \pm 0.01^{\mathrm{a}}$ \\
\hline & & 1 & $874 \pm 0.58^{\mathrm{ab}}$ & $4.76 \pm 0.01^{\mathrm{b}}$ \\
\hline & & 2 & $873 \pm 0.58^{\text {def }}$ & $4.63 \pm 0.01^{\mathrm{c}}$ \\
\hline & \multirow{3}{*}{3} & 0.5 & $872 \pm 0.58^{\mathrm{ef}}$ & $4.60 \pm 0.01^{\mathrm{d}}$ \\
\hline & & 1 & $871 \pm 0.58^{g}$ & $4.52 \pm 0.01^{\mathrm{e}}$ \\
\hline & & 2 & $875 \pm 0.00^{\mathrm{a}}$ & $4.46 \pm 0.01^{\mathrm{f}}$ \\
\hline & \multirow{3}{*}{4} & 0.5 & $874 \pm 0.58^{\text {bcd }}$ & $4.33 \pm 0.01^{\mathrm{g}}$ \\
\hline & & 1 & $873 \pm 0.58^{\text {bcde }}$ & $4.21 \pm 0.00^{\mathrm{h}}$ \\
\hline & & 2 & $873 \pm 0.58^{\text {bcde }}$ & $3.75 \pm 0.01^{\mathrm{i}}$ \\
\hline \multirow{9}{*}{$1.25: 1$} & \multirow{3}{*}{2} & 0.5 & $872 \pm 0.58^{\text {ef }}$ & $3.48 \pm 0.01^{j}$ \\
\hline & & 1 & $874 \pm 0.58^{\text {bcd }}$ & $3.46 \pm 0.00^{\mathrm{k}}$ \\
\hline & & 2 & $873 \pm 0.58^{\text {bcde }}$ & $3.44 \pm 0.01^{1}$ \\
\hline & \multirow{3}{*}{3} & 0.5 & $874 \pm 0.58^{\text {bcd }}$ & $3.40 \pm 0.01^{\mathrm{m}}$ \\
\hline & & 1 & $873 \pm 0.58^{\text {bcde }}$ & $3.34 \pm 0.01^{\mathrm{n}}$ \\
\hline & & 2 & $873 \pm 0.58^{\text {bcde }}$ & $3.34 \pm 0.01^{\mathrm{n}}$ \\
\hline & \multirow{3}{*}{4} & 0.5 & $874 \pm 0.58^{\text {bcd }}$ & $3.22 \pm 0.00^{\circ}$ \\
\hline & & 1 & $873 \pm 0.00^{\text {cde }}$ & $3.21 \pm 0.01^{\mathrm{op}}$ \\
\hline & & 2 & $874 \pm 0.58^{\text {bcd }}$ & $3.21 \pm 0.00^{\mathrm{p}}$ \\
\hline \multirow{9}{*}{$2.5: 1$} & \multirow{3}{*}{2} & 0.5 & $874 \pm 0.58^{\mathrm{ab}}$ & $3.18 \pm 0.01^{\mathrm{q}}$ \\
\hline & & 1 & $873 \pm 0.58^{\text {def }}$ & $3.17 \pm 0.01^{\mathrm{q}}$ \\
\hline & & 2 & $873 \pm 0.58^{\text {bcde }}$ & $3.13 \pm 0.01^{\mathrm{r}}$ \\
\hline & \multirow{3}{*}{3} & 0.5 & $874 \pm 0.58^{\text {bcd }}$ & $3.09 \pm 0.00^{\mathrm{s}}$ \\
\hline & & 1 & $873 \pm 0.58^{\text {bcde }}$ & $3.06 \pm 0.01^{\mathrm{t}}$ \\
\hline & & 2 & $874 \pm 0.58^{\mathrm{ab}}$ & $2.89 \pm 0.01^{\mathrm{u}}$ \\
\hline & \multirow{3}{*}{4} & 0.5 & $872 \pm 0.58^{\mathrm{ef}}$ & $2.74 \pm 0.00^{\mathrm{v}}$ \\
\hline & & 1 & $872 \pm 0.58^{\mathrm{fg}}$ & $2.53 \pm 0.01^{\mathrm{w}}$ \\
\hline & & 2 & $874 \pm 0.00^{\text {bc }}$ & $2.32 \pm 0.01^{x}$ \\
\hline
\end{tabular}

Values with different superscripts in a column were significantly different $(\mathrm{p}<0.05)$. 
On the other hand, the viscosity of biodiesel decreased when the volume ratio of water to crude biodiesel and total flow rate increased from $0.8: 1$ to $2.5: 1$ and from 2 to $4 \mathrm{~L} / \mathrm{min}$, respectively. In addition, the increase in time of the washing process from 0.5 to $2 \mathrm{~min}$, resulted in the viscosity decreasing significantly and presented acceptable viscosities, ranging between 1.9 to $6 \mathrm{~mm}^{2} / \mathrm{s}$, as required by the standards provided by ASTM D6751. Due to the increased amount of wash water which allowed to wash more contaminants from biodiesel, the resulting biodiesel had a reduced viscosity. Therefore, the density and viscosity of biodiesel purification by water washing machines met the standard of biodiesel specified by EN or ASTM.

The color of biodiesel from washing with a water washing machine at a volume ratio of 0.8:1 and flow rate of $4 \mathrm{~L} / \mathrm{min}$ for $0.5 \mathrm{~min}$ is presented in Figure 3 . The contact between washing water and biodiesel might have removed contaminants, causing the biodiesel to be clearer. Moreover, the crude biodiesel purification by the water washing machine in the study reduced the amount of water and time necessary for the washing process, compared with washing by stirring $[4,7]$. These might be beneficial to decrease the costs of biodiesel production.
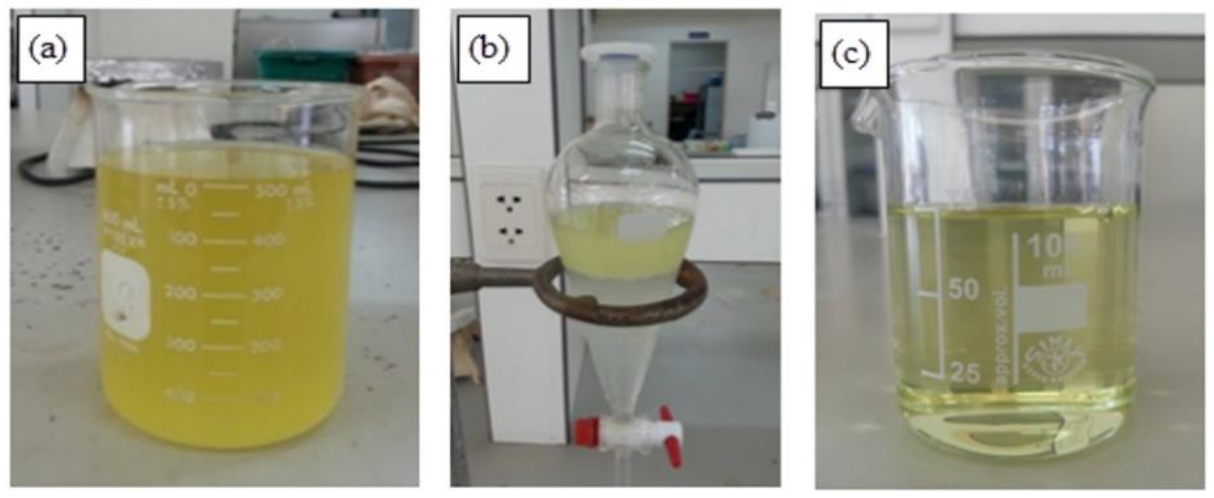

Fig. 3. Crude biodiesel before (a) and after (b) washed by a water washing machine, and biodiesel after washing and drying $(c)$.

\section{Conclusions}

A water washing machine was designed to solve the problems of extensive processing, including large amounts of water and time operation, to purify biodiesel. The effective parameters for the purification of crude biodiesel by water washing machine using the spray washing technique were investigated. After repeating the washing processes three times, the $\mathrm{pH}$ value was close to the $\mathrm{pH}$ value of the tap water before washing. This indicated that the $\mathrm{pH}$ value increased by increasing the number of washing steps. The operation conditions at a volume ratio of $0.8: 1$ (water:crude biodiesel) and flow rate of $4 \mathrm{~L} / \mathrm{min}$ for $0.5 \mathrm{~min}$ were the appropriate conditions for the purification of crude biodiesel by water washing machine. The density and viscosity of biodiesel after purification met the international standards for biodiesel. Based on this study, this water-spray washing technique can be recommended for crude biodiesel purification because it is water-saving and has a short operation time.

The authors would like to acknowledge King Mongkut's Institute of Technology Ladkrabang, Prince of Chumphon Campus, Thailand. 


\section{References}

1. S. S. de Jesus, G. F. Ferreira, M. R. Wolf Maciel, and R. Maciel Filho, Fuel, 235, 11231130, (2019)

2. P.D. Patil, S. Deng, Fuel, 88, 1302-1306, (2009)

3. K. Suthar, A. Dwivedi, and M. Joshipura, Asia-Pac J Chem Eng., 14, e2361, (2019)

4. I.J. Stojković, O.S. Stamenković, D.S. Povrenović, V.B. Veljković, Renew. Sust. Energ. Rev., 32, 1-15 (2014)

5. M. Hayyan, F.S. Mjalli, M.A. Hashim, I.M. AlNashef, Fuel Process. Technol., 91, 116120, (2010)

6. M. Berrios, R.L. Skelton, Chem. Eng. J., 144, 459-465, (2008)

7. M. G. Gomes and D. Pasquini, Environ Prog Sustain., 37, 2093-2099, (2018)

8. S.S. Rahayu and A. Mindaryani, Optimization of Biodiesel Washing by Water Extraction, in Proceedings of the World Congress on Engineering and Computer Science, 24-26 October 2007, San Francisco, USA (2007)

9. P.K. Srivastava and M. Verma, Fuel. 87, 1673-1677 (2008)

10. S. B. Glišić and D. U. Skala, Chem Ind Chem Eng Q., 15, 159-168, (2009)

11. I. M. Atadashi, M. K. Aroua, A. R. A. Aziz, and N. M. N. Sulaiman, Appl. Energy, 88, 4239-4251, (2011)

12. M.A. Bashir, M. Thiri, X. Yang, Y. Yang, A.M. Safdar. J. Clean. Prod., 180, 466-471, (2018)

13. I. M. Atadashi, M. K. Aroua, A. R. Abdul Aziz, and N. M. N. Sulaiman, Egypt. J. Pet., 24, 383-396, (2015)

14. A. Kaewchada and T. Waipanichakarn, The Journal of KMUTNB, 25, 127-135, (2015) 